\title{
Physicochemical characteristics of osmotically dehydrated tomato (Lycopersicon esculentum) under different common drying methods
}

\author{
J. A. V. FAMUREWA ${ }^{1 *}$ and A. O. RAJI ${ }^{2}$ \\ Department of Food Science and Technology, Federal University of Technology, PMB 704, Akure, \\ Ondo State, Nigeria. \\ Department of Agricultural and Environmental Engineering, University of Ibadan, Ibadan, Nigeria. \\ *Corresponding author, E-mail: famurewajav@yahoo.com; Tel: 08062966602
}

\begin{abstract}
This study investigated the effect of different common drying methods on the chemical composition of osmotically dehydrated tomato. The quality of dehydrated tomato is often poor as a result of: collapse of structure, discoloration, tough texture and loss of nutritional values. In this study, osmotic dehydration was combined with other drying methods with a view to investigating the method that will produce high quality product. Combination of sucrose and salt solution was used to soak tomato at $40^{\circ}$ Brix for 4 hours. The osmotically dehydrated samples were subjected to open air (sun), solar cabinet, hot air cabinet and oven drying methods. The proximate composition, colour and vitamin $\mathrm{C}$ of the dried samples were determined. The proximate composition showed that the raw tomato contained fat $1.75 \%$, Ash $27.97 \%$, crude fiber $0.18 \%$, Protein $28.95 \%$ and Carbohydrate $41.15 \%$ while the Sun dried sample contained fat $1.25 \%$, Ash $42.71 \%$, Crude fiber $0.19 \%$, protein $15.74 \%$ and carbohydrate $40.11 \%$. Solar cabinet dried sample contained fat $1.29 \%$, Ash $42.88 \%$, crude fiber $0.26 \%$, protein $15.78 \%$ and carbohydrate $35.79 \%$. Hot air cabinet dried sample contained fat $1.17 \%$, Ash $33.95 \%$, crude fiber $0.25 \%$, protein $14.48 \%$ and carbohydrate $1.17 \%$. Oven dried sample contained, fat $1.15 \%$, Ash $49.34 \%$, crude fiber $0.26 \%$, protein $13.22 \%$ and carbohydrate $36.03 \%$. The vitamin $\mathrm{C}$ and colour measurement for raw, sun dried, solar cabinet dried, hot air cabinet dried and oven dried are $156.7 \mathrm{mg} / 100 \mathrm{~g}$ and $600 \mathrm{~nm}, 79.2 \mathrm{mg} / 100 \mathrm{~g}$ and $610 \mathrm{~nm}, 67.4 \mathrm{mg} / 100 \mathrm{~g}$ and $610 \mathrm{~nm}, 66.6 \mathrm{mg} / 100 \mathrm{~g}$ and $615 \mathrm{~nm}$ and $50 \mathrm{mg} / 100 \mathrm{~g}$ and $620 \mathrm{~nm}$ respectively which indicate the level of red pigmentation. Osmotically dehydrated tomato subjected to solar cabinet drying and sun drying yielded the best quality product based on their proximate and vitamin $\mathrm{C}$ compositions.
\end{abstract}

(C) 2011 International Formulae Group. All rights reserved.

Keywords: Tomato, dehydration, sun drying, proximate composition, ascorbic acid.

\section{INTRODUCTION}

Tomato being a popular fruit, find numerous uses, both in fresh and processed forms. Processed products include ketchup, sauces, pastes and juice. Tomato ranks $13^{\text {th }}$ in vitamin $\mathrm{C}$, with significant amount of lycopene, beta-carotene, magnesium, niacin, iron, phosphorus, potassium, riboflavin, sodium and thiamine (Heng et al., 1990). Many studies confirm that people who eat large amounts of tomatoes experience a reduced risk of cancer (Heng et al., 1990). 
Drying is not a popular way to process tomatoes due to its adverse effect on the quality of the final product. The fruit tissue darkens upon drying, and a strong characteristic flavour is developed (Lewick et al., 2002). However, the interest in production of partially dehydrated tomatoes is increasing due to the possibility to innovate such a traditional product.

Tomato (Lycopersicon esculentum) is subjected to pre-treatment before drying, with a view to improve its characteristic and minimize adverse changes during drying. Such pre-treatment includes alkaline dips, sulphiting, freezing and blanching. Pretreatment excluding the use of chemical may have great potential in food processing (Ade Omowaye et al., 2003). Furthermore, the negative effects of the drying process could be limited by applying specific pre-treatments such as Osmotic dehydration (Lewick et al., 2002).

Partial dehydration and solute intake can be achieved by immersion in concentrated aqueous solution; osmotic dehydration process (Torreggiani et al., 2004). By modifying the extent of the partial dehydration and syrup composition, the end product can be diversified and the chemical, physical and functional properties can be improved upon (Torreggiani et al., 2001). Using syrup with sodium chloride improves the fruit texture while calcium ions interactions with biopolymers, mainly pectin, increases mechanical resistance of the materials undergoing drying (Lewick et al., 2002).

Mainly, these types of concentrated solutions have been used for the osmotic dehydration vizs: sugar (fructose; sucrose), salt and corn syrup, sugar and corn syrup were used for fruit while salt was best used for vegetable because if used in fruit, it will impart a salty taste on them. The kind of sugar utilized as osmotic substance strongly affect the removal of water and equilibrium moisture content. Also, mixed osmotic solution of sodium chloride and sugar, leads to increase in water removal (Lerici et al., 1985). Increase in osmotic solution concentration cause increase in water loss from materials being dehydrated (Famurewa, 2010).

Pre-drying treatment and drying affected substantially the quality of the product. Losses of Lycopene were small (Tripathi \& Nath, 1989; Shi et al., 1999; Zanoni et al., 1999). Moreover, it was found that drying caused little isomerisation of lycopene (Shi et al., 1999). Drying reduced the vitamin C content (Tripathi \& Nath, 1989; Lavelli et al., 1999; Zanoni et al., 1999) increase the 5-hydroxyl mushy 1-2 furfural content (Zanoni et al., 1999) and affected the antioxidant effectiveness of tomato products (Lavelli et al., 1999) especially in their hydrophilic fraction (Lavelli et al., 2000).

Storage of dried tomato pieces had a little effect on their colour (Tripathi \& Nath, 1989) but powdered product was unstable. Calcium chloride greatly increased carotenoid losses but almost completely suppressed browning. Sodium chloride had no effect on carotene losses while metabisulphite had little or no effect on browning of the powder (Baloch et al., 1997).

Osmotic pre-treatment preceding drying was found to be advantageous for quality of the product (Shi et al., 1999). Lycopene loss and isomerisation were reduced compared to air drying and the product possessed properties similar to those of typical dried fruits. The importance of osmotic dehydration include: improvement of the nutritional, sensory and functional properties of foods, extends shelf life and reduction in microbial action. This study therefore aimed at subjecting tomato to osmotic dehydration and further drying to safe moisture level with sun drying, solar drying, cabinet drying and oven drying, to determine the physicochemical characteristic(s) of the resulting products. 


\section{MATERIALS AND METHODS Osmotic dehydration of tomato}

Fresh tomatoes obtained from the main market in Akure, were thoroughly washed in water to remove adhering debris. These were sliced with FUTA Tomato Slicer to a thickness of $2 \mathrm{~mm}$. Osmotic solution of $40^{\circ}$ Brix concentration was prepared using the Equation 1 (Ade Omowaye et al., 2002)

$$
\frac{\mathbf{x}}{\mathbf{x}+\mathbf{y}}=\mathbf{z} \%
$$

Where: $-\mathrm{x}=$ Weight of sugar and salt, $\mathrm{y}=$ Weight of solvent i.e. distilled water, $\mathrm{z}=\%$ of the weight/weight of ${ }^{0} \mathrm{Brix} .2 \mathrm{Kg}$ of tomatoes were immersed in a beaker containing the osmotic solution i.e. sucrose and salt solution for 9 hrs. This solution was stirred at interval of one hour ( $1 \mathrm{hr}$ ) (Ade Omowaye et al., 2002). The samples were then divided into four portions.

\section{Oven dried sample}

The oven was set at a temperature of 40 ${ }^{\circ} \mathrm{C}$ and was left for 5 minutes to equilibrate. $400 \mathrm{~g}$ of the osmotically dehydrated sample was put in an oven until constant weight was achieved.

\section{Hot air cabinet dried sample}

$400 \mathrm{~g}$ of the sample was placed in a cabinet dryer, set at $40{ }^{\circ} \mathrm{C}$ and was left until constant weight was achieved.

\section{Solar cabinet dried sample}

$400 \mathrm{~g}$ of the sample was weighed and placed in a solar dryer until constant weight was achieved.

\section{Open air dried sample}

$400 \mathrm{~g}$ of the sample was spread in a single layer on plywood platform until equilibrium moisture content was achieved.

\section{Milling}

Each of the dried samples was then milled using an attrition mill (FUTA Attrition
Mill), set at $1 \mathrm{~mm}$ gap set, through only one milling run.

\section{Chemical analyses}

This involved the determination of the proximate and ascorbic acid compositions on each sample based on the standard AOAC method (1995). Average of 3 replications was obtained.

\section{Colour (lycopene) determination}

$1 \mathrm{~g}$ of the sample was dissolved in $10 \mathrm{mls}$ of distilled water, stirred for 30 minutes after which the sample was filtered with the use of filter paper, and the filtrate was used for the analysis. $5 \mathrm{ml}$ of the sample were poured inside the colorimeter. The absorbance was read at a wavelength of $450 \mathrm{~nm}$; a graph of absorbance against wavelength was plotted at the peak of the graph, the wavelength corresponding to the standard colour range is read from the standard.

\section{Statistical analysis}

Data were analysed using SPPS for Windows 10. The statistical significance of the observed difference among the means of triplicate readings of experimental results obtained were evaluated by analysis of variance (ANOVA) at 5\% level of significance.

\section{RESULTS AND DISCUSSION}

Table 1 shows the proximate composition of osmotically dehydrated tomato both before and after subjecting it to various types of drying methods. The fat content of the osmosised sample (control) is (1.75\%), this is significantly different to other drying methods except that of sun dried. From the table, it can be seen that the protein content of the control sample is significantly different to the protein content of the dehydrated osmosised tomato using different drying methods. The protein content of the control sample was $(28.95 \%)$ while sun dried was $(15.74 \%)$, solar cabinet dried was (15.28\%), 
hot air cabinet dried (14.48\%) and oven dried was $(13.22 \%)$. This result implies that heat action on dried osmosised tomato might have been responsible for the reduced protein (Fellow, 1990). The ash content of the control sample was $(27.97 \%)$ and that of others are sun dried (42.71\%), solar dried (46.88), cabinet dried $(33.95 \%)$, and oven dried (49.34\%). This result on ash content showed that there was more ash in dried tomato than control tomato; this implies that there are more combustible materials in dried tomato compared to the raw tomato sample subjected to osmotic dehydration. This can be attributed to the drying methods. The difference in fibre content of the control and dried tomatoes indicate more crude fibre in the dried ones; it also implies that there are more indigestible materials in dried tomato. It can thus be said that heat affects the proximate quality of tomato.

Browning index, which is an indicator of the extent of browning, was higher at high temperature. Direct exposure of sliced tomato for longer time of dehydration and higher heat may be considered as a reason for these changes.

Dried fruit are good sources of energy, because they contain concentrated fruit sugars. Fruit also contains a large amount of vitamins and minerals. The drying process however, destroys some of the vitamins, especially A and C. Exposing fruits to sulphur destroys thiamine, one of the B vitamins, but fruits are not important sources of thiamine. Many dried fruits are rich in riboflavin and iron. Vegetables are good sources of minerals and the $\mathrm{B}$ vitamins, thiamine, riboflavin, and niacin. Both fruits and vegetables provide useful amounts of the fiber (bulk) man needs.

Table 2 shows the vitamin $\mathrm{C}$ content of the samples. It is shown that the vitamin $\mathrm{C}$ content of the control sample was 156.7 $\mathrm{mg} / 100 \mathrm{~g}$ while that of sun dried was 89.2 $\mathrm{mg} / 100 \mathrm{~g}$ the solar cabinet dried sample was $67.4 \mathrm{mg} / 100 \mathrm{~g}$; the hot air cabinet dried sample was $66.6 \mathrm{mg} / 100 \mathrm{~g}$ and oven dried sample was $50 \mathrm{mg} / 100 \mathrm{~g}$. The ascorbic acid (vitamin C) contents of the dried samples are less than that of the control. The variation may be due to leaching of the vitamin being water soluble and oxidation due to longer period and higher temperature of drying. This was in agreement with the works of Shi et al. (1999) and Famurewa (2010), they reported that drying of vegetable leads to some losses of ascorbic and sensory characteristics. It was added that more severe drying conditions in oven caused higher losses of ascorbic acid.

The result of colour determination indicated that all the dried samples were having red colour as the values are within the range for red (600-630 nm) as presented in Table 3. This is an indication that osmotically dehydrating tomato assists in retaining the original colour. This is promising as tomatoes colour are lost during drying without pretreatment.

Table 1: Proximate composition of dried tomato on dry basis.

\begin{tabular}{lccccc}
\hline Sample & Control & Sun dried & Solar cabinet dried & Tray dried & Oven dried \\
\hline$\%$ fat & $1.75^{\mathrm{a}}$ & $1.25^{\mathrm{ab}}$ & $1.29^{\mathrm{b}}$ & $1.17^{\mathrm{c}}$ & $1.15^{\mathrm{c}}$ \\
$\%$ ash & $27.97^{\mathrm{e}}$ & $42.71^{\mathrm{c}}$ & $46.88^{\mathrm{b}}$ & $33.95^{\mathrm{d}}$ & $49.34^{\mathrm{a}}$ \\
$\%$ crude fibre & $0.18^{\mathrm{b}}$ & $0.19^{\mathrm{b}}$ & $0.26^{\mathrm{a}}$ & $0.25^{\mathrm{a}}$ & $0.26^{\mathrm{a}}$ \\
$\%$ protein & $28.95^{\mathrm{a}}$ & $15.74^{\mathrm{b}}$ & $15.78^{\mathrm{b}}$ & $14.48^{\mathrm{c}}$ & $13.22^{\mathrm{d}}$ \\
$\%$ carbohydrate & $41.15^{\mathrm{b}}$ & $40.11^{\mathrm{c}}$ & $35.79^{\mathrm{e}}$ & $50.15^{\mathrm{a}}$ & $36.03^{\mathrm{d}}$ \\
\hline \multicolumn{4}{l}{ Mean followed by different letter horizontally are significantly different at $(\mathrm{P}>0.05)$} &
\end{tabular}

Mean followed by different letter horizontally are significantly different at $(\mathrm{P}>0.05)$ 
Table 2: Vitamin $\mathrm{C}$ content of the dried tomato.

\begin{tabular}{lc}
\hline Samples & Vitamin c (mg/100g) \\
\hline Control & 156.7 \\
Sun dried & 89.2 \\
Solar Cabinet dried & 67.4 \\
Tray dried & 66.6 \\
Oven dried & 50 \\
\hline
\end{tabular}

Table 3: Colour wavelength of the samples.

\begin{tabular}{lc}
\hline Samples & Colour wavelength $(\mathbf{n m})$ \\
\hline Control & 600 \\
Sun dried & 610 \\
Solar Cabinet dried & 610 \\
Tray dried & 615 \\
Oven dried & 620 \\
\hline
\end{tabular}

\section{Conclusions}

It can be concluded from the results of the study that drying affects the proximate composition as well as vitamin $\mathrm{C}$ of tomato with solar drying retained the highest amount of fat, protein and crude fibre, while sun dried samples retained the highest amount of vitamin $\mathrm{C}$ and oven drying at $50{ }^{\circ} \mathrm{C}$ has a significant reduction. Dehydrated osmosised tomatoes highly retained their red colour. Therefore, to obtain dried tomatoes with red colour maintained, osmotic dehydration as pre-treatment is recommended and to retain the vitamin $\mathrm{C}$ and proximate composition on further drying, solar cabinet drying should be used.

\section{REFERENCES}

Ade-Omowaye BIO, Pastogi NK, Angersbach A, Knorr D. 2002. Osmotic dehydration behaviour of red paprika (Capsicum annum L.). Journal of Food Science, 67: 1790-1796.

AOAC. 1995: Official Methods of Analysis $\left(16^{\text {th }}\right.$ edn). Association of Official Analytical Chemist: Washington, DC.
Baloch WA, Khan Baloch AK. 1997. Influence of chemical additives on the stability of dried tomato powder. International Journal of Food Science and Technology, 32(2): 120

Famurewa JAV. 2010. Effect of Drying methods on Chemical Composition of Red Bell Pepper (Capsicum annum). Journal of Applied Tropical Agriculture. Special issue: 160-162.

Fellow PJ. 1990. Food Processing, Principle of Practice. Published by Ellis Horwood.

Heng W, Guilbert S, Cuq JL. 1990. Osmotic dehydration of papaya: Influence of process variables on the product quality. Science des Aliments, 10: 831-848.

Lavelli V, Hippeli S, Peri C, Elstner EF. 1999. Evaluation of radical scavenging activity of fresh and air-dried tomatoes by three model reactions. Journal of Agricultural and Food Chemistry, 47(9): 3826-3831.

Lavelli V, Peri C, Rizzolo A. 2000. Antioxidant activity of tomato products as studies by Model Reactions using xanthine oxidase, myeloperoxidase, and copper-induced lipid peroxidation. 
Journal of Agricultural and Food Chemistry, 48(5): 1442 - 1448.

Lerici CRE, Pinnavaia RM, Dalla, Bartoluce L. 1985. Osmotic agent on drying behavior and product quality. Journal of food Science, 95: 1217-1218.

Lewick PP, Vule H, Pormaranska-Laznka W. 2002. Effect of Pretreatment on Convective Drying of Tomato, Journals of Food Engineering, 54: 141-146.

Shi JX, Lcmegher M, Wang SL, Liptray A. 1999. Application of osmotic treatment in tomato processing. Food Research International, 30: 669-674.

Tripathi RN, Nath N. 1989. Effect of starch dipping on quality of dehydrated tomato slices. Journal of Food Science and Technology, India, 26: 137-141.
Torreggiani D, Maff D, Bertolo G, Brambilla, A. 2004. Effect of osmotic dehydration time on strawberry tissue structure. In ICEF 8 (Eight) International Congress on Engineering and Food. Book of Abstract April 9-13, pp 211.

Torreggiani D, Glangiacomo R, Abbo E. 2001. Osmotic dehydration of fruit Part 1 Sugar exchange between fruits and extracting syrups. Journals of Food Processing and Preservation, 11: 183195.

Zanoni B, Peri C, Nani R, Lavelli V. 1999. Oxidative Heat Damage to Tomato Halves as Affected by Drying. Food Research International, 31(5): 395-401. 